\title{
SYNTHESIS AND CHARACTERIZATION OF OXOVANADIUM (IV) DITHIOCARBAMATES WITH PYRIDINE
}

Antonio L. Doadrio*, José Sotelo and Ana Fernández-Ruano

Departamento de Química Inorgánica y Bioinorgánica, Facultad de Farmacia, Universidad Complutense, 28040 Madrid, Spain

Recebido em 19/02/01; aceito em 12/12/01

\begin{abstract}
SYNTHESIS AND CHARACTERIZATION OF OXOVANADIUM (IV) DITHIOCARBAMATES WITH PYRIDINE We report the synthesis and study of a new series of oxovanadium (IV) dithiocarbamate adducts and derivatives with pyridine and cyclohexyl, di-iso-butyl, di-n-propyl, anilin, morpholin, piperidin and di-iso-propyl amines. The complexes have been characterized by analytical, magnetochemical, IR, visible-UV spectral and thermal studies, and are assigned the formulas [VO(L) $]$.py, where $\mathrm{L}=$ cyclohexyl, di-iso-butyl, di-n-propyl, anilin dithiocarbamate and $\left[\mathrm{VO}(\mathrm{OH})(\mathrm{L})(\mathrm{py})_{2}\right] \mathrm{OH} \cdot \mathrm{H}_{2} \mathrm{O}(\mathrm{L}=$ morpholin, piperidin and diiso-propyl dithiocarbamate).

The effect of the adduct formation on the $\mathrm{p}_{\mathrm{v}=0}$ bound is discussed in terms of the IR (V=O, V-S and V-N stretching frequencies) and electronic spectra (d-d transitions).
\end{abstract}

Keywords: vanadium(IV); dithiocarbamates; pyridine.

\section{INTRODUCTION}

In former investigations, we have synthesized and characterized five-coordinated oxovanadium(IV) complexes. Oxovanadium (IV) complexes with dithiocarbamates show a square pyramidal structure ${ }^{1}$, which can react with Lewis bases to form mainly stable adducts, in which the base occupies the sixth coordination position in an octahedral complex ${ }^{2}$, as in the oxovanadium (IV) xanthates ${ }^{3}$ and dithiocarboxylates ${ }^{4,5}$. So, the adduct formula is $\left[\mathrm{VO}(\mathrm{L})_{2}\right]$.B ( $\mathrm{L}=$ bidentate ligand, $\mathrm{B}=$ base).

In this paper, we report the synthesis and characterization of a new series of oxovanadium(IV) dithiocarbamates complexes with pyridine, which also form complexes of the general formula $\left[\mathrm{VO}(\mathrm{L})_{2}\right]$.py, noted as adducts, and alternating complexes of the general formula $\left[\mathrm{VO}(\mathrm{OH})(\mathrm{L})(\mathrm{py})_{2}\right] \mathrm{OH} \cdot \mathrm{H}_{2} \mathrm{O}$, that are soluble in water and noted as derivatives.

We have studied the variations in the IR and electronic spectra caused by the addition of the organic base.

The study of these complexes by IR and electronic spectroscopy, magnetic susceptibilities, thermal methods and analytical data, shows that the adducts stoichiometry is 1:1 (base:complex) and in the derivatives 2:1 (base: metal) with lost of a ligand. From IR and electronic spectral data, we assign a six-coordinated distorted octahedral structure for the adducts $\left[\mathrm{VO}(\mathrm{L})_{2}\right]$.py, and possible six-coordinated structure for the derivatives $\left[\mathrm{VO}(\mathrm{OH})(\mathrm{L})(\mathrm{py})_{2}\right] \mathrm{OH} . \mathrm{H}_{2} \mathrm{O}$ from the metallic center. We have also observed a relationship between the $\mathrm{V}=\mathrm{O}, \mathrm{V}-\mathrm{S}$ stretching modes and the ${ }^{2} \mathrm{~B}_{2} \rightarrow{ }^{2} \mathrm{~B}_{1},{ }^{2} \mathrm{~B}_{2} \rightarrow{ }^{2} \mathrm{E}(\mathrm{I})$ transition frequencies.

\section{EXPERIMENTAL PART}

\section{MATERIALS AND METHODS}

\section{Starting materials}

$\mathrm{VOSO}_{4} .5 \mathrm{H}_{2} \mathrm{O}$ and Pyridine were Merck commercial products and used as supplied. Cyclohexyl, di-iso-butyl, di-n-propyl, anilin, morpholin, piperidin and di-iso-propyl amines were Merck or Aldrich commercial

*e-mail: antoniov@farm.ucm.es products. The solvents used were Merck (analytical grade). Solutions for absorption spectra were prepared using pyridine. All these reagents were supplied by Micron Analítica S.A. (Madrid, Spain).

\section{Analytical procedures}

$\mathrm{C}, \mathrm{H}$ and $\mathrm{S}$ elemental analyses were made on a Perkin-Elmer model 240B (Boston, Massachusetts, USA) analyzer and N elemental analysis using a Leco model SC32 analyzer (Leco Corporation, St Joseph, USA). Vanadium was determined by atomic absorption spectrophotometry after decomposition of the adduct by heating in a 1:1 concentrated $\mathrm{HNO}_{3}: \mathrm{H}_{2} \mathrm{SO}_{4}$ mixture or dissolving the derivative in water. The melting points were determined on a melting point apparatus by using open capillary tubes and the conductivity measurements were made on a Metrohm Herisau E365B conductometer at room temperature.

\section{Methods}

Magnetic susceptibilities were measured by the Gouy method at room temperature on a Mettler H-51A.R. balance (Mettler Toledo, Greifensee Switzerland) using a Newport electromagnet, made from Oxford Instrument (Oxfordshire, UK). Molar susceptibilities were corrected for the diamagnetism of the constituent molecules. ${ }^{6,7}$

The IR spectra were recorded as $\mathrm{KBr}$ pellets on a Perkin Elmer recording spectrophotometer model 283.

The visible/near U.V. spectra of the complexes were determined in the range of 300-900 nm on a Beckman DK 2A (Beckman Coulter, Inc, Fullerton, USA) recording spectrophotometer using solution of the complexes in pyridine (derivatives in water).

Thermograms were recorded on a Mettler HE20 thermobalance with Mettler DSC20 module and DSC were determined on a Mettler TA3000 system in static air with a heating rate of $10^{\circ} \mathrm{C}$ per minute.

\section{Preparations}

Oxovanadium(IV) dithiocarbamates complexes $\mathrm{VO}\left(\mathrm{RNCS}_{2}\right)_{2}$ were prepared by the same general method described in another paper. $^{1}$ 
$\left\{\left[\mathrm{C}_{6} \mathrm{H}_{11} \mathrm{HNCS}_{2}\right]_{2} \mathrm{VO}\right\} . p y: 1.5 \mathrm{~g}\left(3.03 .10^{-3} \mathrm{~mol}\right)$ of the complex previously obtained (oxovanadium(IV) cyclohexyl dithiocarbamate) was dissolved in pyridine $(50 \mathrm{~mL})$ by continuous stirring for 3 hours at room temperature. After cooling for 24 hours, the adduct was separated by filtration in vacuo, washed repeatedly with cool water and dried over $\mathrm{P}_{4} \mathrm{O}_{10}$ in a nitrogen atmosphere. Yield: $50 \%$.

Similar procedure was used for the other complexes with di-isobutyl, di-n-propyl, anilin, morpholin, piperidin and di-iso-propyl dithiocarbamate as ligands. The yields were 50-70\%. (see Table 1).

\section{RESULTS AND DISCUSSION}

The adducts $\left[\mathrm{VO}(\mathrm{L})_{2}\right]$.py and the $\left[\mathrm{VO}(\mathrm{OH})(\mathrm{L})(\mathrm{py})_{2}\right] \mathrm{OH} . \mathrm{H}_{2} \mathrm{O}$ derivatives were prepared by the direct reaction between the $\mathrm{VO}\left(\mathrm{RNCS}_{2}\right)_{2}$ complex and pyridine at room temperature. The source of the water and consequently the $\mathrm{OH}^{-}$could be the solvent pyridine. Cyclohexyl, di-iso-butyl, di-n-propyl and anilin dithiocarbamate ligands are adducts, and morpholin, piperidin and di-iso-propyl dithiocarbamates are derivatives. The adducts are soluble in pyridine and DMSO, but less soluble in dichloromethane, benzene or hexane. The derivatives are soluble in water, methanol or ethanol, and insoluble in organic solvents.

The complexes obtained in this study gave analytical results which are concordant with the formulas assigned, as summarised in Table 1.

The molar conductivity values calculated from the conductivities measured on millimolar solutions of the derivatives complexes $\left[\mathrm{VO}(\mathrm{OH})(\mathrm{L})(\mathrm{py})_{2}\right] \mathrm{OH} \cdot \mathrm{H}_{2} \mathrm{O}$, in water, support the electrolytic nature of the complexes.

All these complexes are paramagnetic, with values of the magnetic moments between 1.6 to $1.75 \mathrm{BM}$ (see Table 1). These results show the existence of monomeric species of oxovanadium (IV).

The most relevant bands in the infrared spectra of the complexes are presented in Table 2. The IR spectra of the adducts [VO $\left.(\mathrm{L})_{2}\right]$.py, exhibit a very strong band at $990-975 \mathrm{~cm}^{-1}$ and the derivatives,

Table 1. Physical and Analytical Data of $\left[\mathrm{VO}(\mathrm{L})_{2}\right]$.py and $\left[\mathrm{VO}(\mathrm{OH})(\mathrm{L})(\mathrm{py})_{2}\right] \mathrm{OH} \cdot \mathrm{H}_{2} \mathrm{O}$ complexes

\begin{tabular}{|c|c|c|c|c|c|c|c|c|c|c|}
\hline Compound & M.P. $\left({ }^{\circ} \mathrm{C}\right)$ & & $\mathrm{C}$ & $\mathrm{H}$ & $S$ & $\mathrm{~N}$ & $\mathrm{~V}$ & $\%$ Yield & $\begin{array}{c}\text { Molar }^{\mathrm{b}} \\
\text { conductance }\end{array}$ & $\mu(\mathrm{BM})$ \\
\hline$\left[\mathrm{VO}\left(\mathrm{C}_{6} \mathrm{H}_{11} \mathrm{HNCS}_{2}\right)_{2}\right] \cdot \mathrm{py}$ & 245 & $\begin{array}{l}\text { \%Calcd } \\
\% \text { Found }\end{array}$ & $\begin{array}{l}46.2 \\
47.9\end{array}$ & $\begin{array}{l}5.7 \\
6.0\end{array}$ & $\begin{array}{l}26.0 \\
26.1\end{array}$ & $\begin{array}{l}8.5 \\
8.7\end{array}$ & $\begin{array}{l}10.2 \\
10.8\end{array}$ & 50 & & 1.65 \\
\hline$\left.\left[\mathrm{VO}\left(i-\mathrm{C}_{4} \mathrm{H}_{9}\right)_{2} \mathrm{NCS}_{2}\right)_{2}\right] \cdot \mathrm{py}$ & 232 & $\begin{array}{l}\% \text { Calcd } \\
\% \text { Found }\end{array}$ & $\begin{array}{l}49.8 \\
50.0\end{array}$ & $\begin{array}{l}7.4 \\
7.2\end{array}$ & $\begin{array}{l}23.1 \\
23.9\end{array}$ & $\begin{array}{l}7.6 \\
8.1\end{array}$ & $\begin{array}{l}9.0 \\
9.8\end{array}$ & 65 & & 1.60 \\
\hline$\left.\left[\mathrm{VO}\left(\mathrm{C}_{3} \mathrm{H}_{7}\right)_{2} \mathrm{NCS}_{2}\right)_{2}\right] \cdot \mathrm{py}$ & 235 & $\begin{array}{l}\text { \%Calcd } \\
\% \text { Found }\end{array}$ & $\begin{array}{l}45.8 \\
46.1\end{array}$ & $\begin{array}{l}6.6 \\
7.2\end{array}$ & $\begin{array}{l}25.7 \\
25.8\end{array}$ & $\begin{array}{l}8.4 \\
8.9\end{array}$ & $\begin{array}{l}10.1 \\
10.6\end{array}$ & 70 & & 1.68 \\
\hline$\left[\mathrm{VO}\left(\mathrm{C}_{6} \mathrm{H}_{5} \mathrm{NCS}_{2}\right)_{2}\right] \cdot \mathrm{py}$ & 235 & $\begin{array}{l}\text { \%Calcd } \\
\% \text { Found }\end{array}$ & $\begin{array}{l}47.5 \\
47.9\end{array}$ & $\begin{array}{l}3.1 \\
3.3\end{array}$ & $\begin{array}{l}26.7 \\
26.8\end{array}$ & $\begin{array}{l}8.8 \\
9.2\end{array}$ & $\begin{array}{l}10.4 \\
10.8\end{array}$ & 52 & & 1.75 \\
\hline$\left[\mathrm{VO}(\mathrm{OH})\left(i-\mathrm{C}_{3} \mathrm{H}_{7} \mathrm{NCS}_{2}\right)(\mathrm{py})_{2}\right] \mathrm{OH} \cdot \mathrm{H}_{2} \mathrm{O}$ & 234 & $\begin{array}{l}\% \text { Calcd } \\
\% \text { Found }\end{array}$ & $\begin{array}{l}45.0 \\
46.8\end{array}$ & $\begin{array}{l}6.2 \\
7.6\end{array}$ & $\begin{array}{l}14.1 \\
14.8\end{array}$ & $\begin{array}{l}9.3 \\
8.2\end{array}$ & $\begin{array}{l}11.1 \\
11.7\end{array}$ & 60 & 300 & 1.70 \\
\hline$\left[\mathrm{VO}(\mathrm{OH})\left(\mathrm{C}_{5} \mathrm{H}_{10} \mathrm{NCS}_{2}\right)(\mathrm{py})_{2}\right] \mathrm{OH} \cdot \mathrm{H}_{2} \mathrm{O}$ & 230 & $\begin{array}{l}\% \text { Calcd } \\
\% \text { Found }\end{array}$ & $\begin{array}{l}43.9 \\
44.2\end{array}$ & $\begin{array}{l}5.5 \\
6.1\end{array}$ & $\begin{array}{l}14.6 \\
15.1\end{array}$ & $\begin{array}{l}9.6 \\
9.7\end{array}$ & $\begin{array}{l}11.5 \\
12.1\end{array}$ & 70 & 280 & 1.72 \\
\hline$\left[\mathrm{VO}(\mathrm{OH})\left(\mathrm{C}_{4} \mathrm{H}_{8} \mathrm{ONCS}_{2}\right)(\mathrm{py})_{2}\right] \mathrm{OH} \cdot \mathrm{H}_{2} \mathrm{O}$ & 240 & $\begin{array}{l}\text { \%Calcd } \\
\% \text { Fou nd }\end{array}$ & $\begin{array}{l}41.0 \\
41.2\end{array}$ & $\begin{array}{l}5.0 \\
5.2\end{array}$ & $\begin{array}{l}14.6 \\
15.1\end{array}$ & $\begin{array}{l}9.6 \\
9.8\end{array}$ & $\begin{array}{l}11.4 \\
11.1\end{array}$ & 60 & 305 & 1.71 \\
\hline
\end{tabular}

adecomposed without melting. bin $\mathrm{H}_{2} \mathrm{O}\left(\mathrm{ohm}^{-1} \mathrm{~cm}^{2} \mathrm{~mol}^{-1}\right.$ at $\left.25^{\circ} \mathrm{C}\right)$.

Table 2. Infrared spectral data $\left(\mathrm{cm}^{-1}\right)$ of $\left[\mathrm{VO}(\mathrm{L})_{2}\right] \cdot \mathrm{py},\left[\mathrm{VO}(\mathrm{OH})(\mathrm{L})(\mathrm{py})_{2}\right] \mathrm{OH} \cdot \mathrm{H}_{2} \mathrm{O}$ and $\left[\mathrm{VO}(\mathrm{L})_{2}\right]$ complexes

\begin{tabular}{|c|c|c|c|c|c|c|c|c|}
\hline \multirow{3}{*}{$\begin{array}{l}\text { Compound } \\
{\left[\mathrm{VO}\left(\mathrm{C}_{6} \mathrm{H}_{11} \mathrm{HNCS}_{2}\right)_{2}\right] \cdot p y} \\
{\left[\mathrm{VO}\left(\mathrm{C}_{6} \mathrm{H}_{11} \mathrm{NHCS}_{2}\right)_{2}\right]^{3}}\end{array}$} & \multirow[t]{3}{*}{$v\left(\mathrm{NH}^{+}\right)$} & \multirow{2}{*}{$\frac{v(\mathrm{CN})}{1510}$} & \multirow{2}{*}{$\frac{v(\mathrm{CS})}{1110-1150}$} & \multirow[t]{2}{*}{$v(\mathrm{VOH})$} & \multirow{2}{*}{$\frac{v(\mathrm{VO})}{975}$} & \multicolumn{2}{|c|}{$v(\mathrm{VS})$} & \multirow{2}{*}{$\frac{v(\mathrm{VN})}{340}$} \\
\hline & & & & & & $420^{1}$ & $400^{2}$ & \\
\hline & & 1500 & 1140 & & 980 & 390 & 350 & \\
\hline$\left.\left[\mathrm{VO}\left(i-\mathrm{C}_{4} \mathrm{H}_{9}\right)_{2} \mathrm{NCS}_{2}\right)_{2}\right] \cdot \mathrm{py}$ & & 1490 & $1110-1150$ & & 990 & 400 & 350 & 330 \\
\hline$\left.\left[\mathrm{VO}\left(i-\mathrm{C}_{4} \mathrm{H}_{9}\right)_{2} \mathrm{NCS}_{2}\right)_{2}\right]^{3}$ & & 1490 & 1100 & & 1000 & 380 & & \\
\hline$\left.\left[\mathrm{VO}\left(\mathrm{C}_{3} \mathrm{H}_{7}\right)_{2} \mathrm{NCS}_{2}\right)_{2}\right] \cdot \mathrm{py}$ & & 1520 & $1130-1180$ & & 980 & 410 & 380 & 330 \\
\hline$\left.\left[\mathrm{VO}\left(\mathrm{C}_{3} \mathrm{H}_{7}\right)_{2} \mathrm{NCS}_{2}\right)_{2}\right]$ & & 1505 & 1110 & & 985 & 380 & 360 & \\
\hline$\left[\mathrm{VO}\left(\mathrm{C}_{6} \mathrm{H}_{5} \mathrm{NCS}_{2}\right)_{2}\right] \cdot \mathrm{py}$ & & 1500 & $1100-1180$ & & 985 & 420 & 400 & 330 \\
\hline$\left[\mathrm{VO}\left(\mathrm{C}_{6} \mathrm{H}_{5} \mathrm{NCS}_{2}\right)_{2}\right]$ & & 1500 & 1150 & & 990 & 370 & 340 & \\
\hline$\left[\mathrm{VO}(\mathrm{OH})\left(i-\mathrm{C}_{3} \mathrm{H}_{7} \mathrm{NCS}_{2}\right)(\mathrm{py})_{2}\right] \mathrm{OH} \cdot \mathrm{H}_{2} \mathrm{O}$ & 2480 & 1460 & 1110 & 740 & 970 & 430 & 390 & 330 \\
\hline$\left[\mathrm{VO}\left(i-\mathrm{C}_{3} \mathrm{H}_{7} \mathrm{NCS}_{2}\right)_{2}\right]^{3}$ & & 1490 & 1110 & & 980 & 370 & & \\
\hline$\left[\mathrm{VO}(\mathrm{OH})\left(\mathrm{C}_{5} \mathrm{H}_{10} \mathrm{NCS}_{2}\right)(\mathrm{py})_{2}\right] \mathrm{OH} \cdot \mathrm{H}_{2} \mathrm{O}$ & 2500 & 1460 & 1110 & 740 & 975 & 400 & 380 & 330 \\
\hline$\left[\mathrm{VO}\left(\mathrm{C}_{5} \mathrm{H}_{10} \mathrm{NCS}_{2}\right)_{2}\right]^{3}$ & & 1500 & 1110 & & 980 & 380 & 350 & \\
\hline$\left[\mathrm{VO}(\mathrm{OH})\left(\mathrm{C}_{4} \mathrm{H}_{8} \mathrm{ONCS}_{2}\right)(\mathrm{py})_{2}\right] \mathrm{OH} \cdot \mathrm{H}_{2} \mathrm{O}$ & 2480 & 1420 & 1110 & 750 & 975 & 440 & 410 & 325 \\
\hline$\left[\mathrm{VO}\left(\mathrm{C}_{4} \mathrm{H}_{8} \mathrm{ONCS}_{2}\right)_{2}\right]^{3}$ & & 1495 & 1100 & & 985 & 375 & 355 & \\
\hline
\end{tabular}

${ }^{1}$ antisymmetric. ${ }^{2}$ symmetric. ${ }^{3}$ ref 1 
$\left[\mathrm{VO}(\mathrm{OH})(\mathrm{L})(\mathrm{py})_{2}\right] \mathrm{OH} . \mathrm{H}_{2} \mathrm{O}$ at $975-970 \mathrm{~cm}^{-1}$, which is attributed to the stretching vibration of the terminal $\mathrm{V}=\mathrm{O}$ bond. If we compare the $\mathrm{VO}\left(\mathrm{RNCS}_{2}\right)_{2}$ complex with the adduct or derivative, we observed that these show the $\mathrm{V}=\mathrm{O}$ band displaced to lower frequencies (990$\left.970 \mathrm{~cm}^{-1}\right)$ than the complex $\left(1000-980 \mathrm{~cm}^{-1}\right)$. Similar results are obtained in other complexes of oxovanadium(IV) with dithiocarbamates $^{8}$, dithiocarboxylates ${ }^{9}, 8$-quinolinate ${ }^{10}$, benzoylacetonate ${ }^{11}$ or dibenzoylmethanate ${ }^{12}$ as ligands. This displacement can be attributed to the electronic donation of the base to the vanadium $(\mathrm{N} \rightarrow \mathrm{V})$, which increases the electron density on the metal d-orbitals, and consequently the $\mathrm{p}_{\pi} \rightarrow \mathrm{d}_{\pi}$ donation from the oxygen atom to vanadium is expected to be reduced.

The IR spectra of the adducts and derivatives exhibit a medium band at $340-325 \mathrm{~cm}^{-1}$ which are assigned to the stretching vibration of the $\mathrm{V}-\mathrm{N}_{\text {(base) }}$ bond. ${ }^{2,10-12}$ This band is not present in the complex $\mathrm{VO}\left(\mathrm{RNCS}_{2}\right)_{2}$.
The IR spectra of all the complexes studied in this work show two bands at $440-370 \mathrm{~cm}^{-1}$ and $410-340 \mathrm{~cm}^{-1}$, which are assigned to the antisymmetrical and symmetrical vibrations respectively, of the stretching $\mathrm{V}-\mathrm{S}_{\text {ligand }}$. Both bands are displaced to greater frequencies than in the complex $\mathrm{VO}\left(\mathrm{RNCS}_{2}\right)_{2}$, according to the displacement to lower frequencies observed in the stretching vibration $\mathrm{V}=\mathrm{O}$ bond.

One C-S stretching frequency (n(CSS), $1180-1100 \mathrm{~cm}^{-1}$ ) is observed in the IR spectra of all the complexes. The presence of the an only C-S band can be due to the greatest contribution of the resonant form $\left(\mathrm{RN}^{+} \mathrm{CS}_{2}^{-}\right)$in the adducts and derivatives.

The IR spectra of the derivatives $\left[\mathrm{VO}(\mathrm{OH})(\mathrm{L})(\mathrm{py})_{2}\right] \mathrm{OH} . \mathrm{H}_{2} \mathrm{O}$ exhibit a band at $2480-2500 \mathrm{~cm}^{-1}$, which is assigned to the stretching vibration of the $\mathrm{NH}^{+}$bond, and a band at $750-740 \mathrm{~cm}^{-1}$, which can be assign to the vibration of the $\mathrm{V}-\mathrm{OH}$ bond. These bands are not present in the adducts $\left[\mathrm{VO}\left(\mathrm{RNCS}_{2}\right)_{2}\right]$.py nor in the $\mathrm{VO}\left(\mathrm{RNCS}_{2}\right)_{2}$ complexes.

Finally, one stretching frequency at $1520-1420 \mathrm{~cm}^{-1}$ is observed

Table 3. Electronic Absorption Spectra $\left(\mathrm{cm}^{-1}\right)$ in pyridine

\begin{tabular}{|c|c|c|c|}
\hline Compound & ${ }^{2} \mathrm{~B}_{2} \rightarrow{ }^{2} \mathrm{E}(\mathrm{I})$ & ${ }^{2} \mathrm{~B}_{2} \rightarrow{ }^{2} \mathrm{~B}_{1}$ & ${ }^{2} \mathrm{~B}_{2} \rightarrow{ }^{2} \mathrm{~A}_{1}$ \\
\hline$\left[\mathrm{VO}\left(\mathrm{C}_{6} \mathrm{H}_{11} \mathrm{HNCS}_{2}\right)_{2}\right] \cdot \mathrm{py}$ & 14000 & 20230 & 24500 \\
\hline$\left[\mathrm{VO}\left(\mathrm{C}_{6}^{6} \mathrm{H}_{11} \mathrm{NHCS}_{2}\right)_{2}\right]^{1}$ & 16666 & 15290 & 20661 \\
\hline$\left.\left[\mathrm{VO}\left(i-\mathrm{C}_{4} \mathrm{H}_{9}\right)_{2} \mathrm{NCS}_{2}\right)_{2}\right] \cdot \mathrm{py}$ & 14000 & 20400 & 23696 \\
\hline$\left.\left[\mathrm{VO}\left(i-\mathrm{C}_{4}^{4} \mathrm{H}_{9}\right)_{2} \mathrm{NCS}_{2}\right)_{2}\right]^{1}$ & 17806 & 15243 & 20833 \\
\hline$\left.\left[\mathrm{VO}\left(\mathrm{C}_{3} \mathrm{H}_{7}\right)_{2} \mathrm{NCS}_{2}\right)_{2}\right] \cdot \mathrm{py}$ & 14000 & 20400 & Not detected \\
\hline$\left.\left[\mathrm{VO}\left(\mathrm{C}_{3}^{3} \mathrm{H}_{7}\right)_{2} \mathrm{NCS}_{2}\right)_{2}\right]$ & 16666 & 15151 & 20408 \\
\hline$\overline{\left[\mathrm{VO}\left(\mathrm{C}_{6} \mathrm{H}_{5} \mathrm{NCS}_{2}\right)_{2}\right] \cdot \mathrm{py}}$ & 14000 & 20400 & 23696 \\
\hline$\left[\mathrm{VO}\left(\mathrm{C}_{6}^{6} \mathrm{H}_{5}^{5} \mathrm{NCS}_{2}\right)_{2}\right]$ & 16666 & 15384 & 21276 \\
\hline$\left[\mathrm{VO}(\mathrm{OH})\left(i-\mathrm{C}_{3} \mathrm{H}_{7} \mathrm{NCS}_{2}\right)(\mathrm{py})_{2}\right] \mathrm{OH} \cdot \mathrm{H}_{2} \mathrm{O}$ & Not detected & 20400 & 23696 \\
\hline$\left[\mathrm{VO}\left(i-\mathrm{C}_{3} \mathrm{H}_{7} \mathrm{NCS}_{2}\right)_{2}\right]^{1}$ & 16949 & 15197 & 20241 \\
\hline$\left[\mathrm{VO}(\mathrm{OH})\left(\mathrm{C}_{5} \mathrm{H}_{10} \mathrm{NCS}_{2}\right)(\mathrm{py})_{2}\right] \mathrm{OH} . \mathrm{H}_{2} \mathrm{O}$ & 14000 & 20400 & Not detected \\
\hline$\left[\mathrm{VO}\left(\mathrm{C}_{5} \mathrm{H}_{10} \mathrm{NCS}_{2}\right)_{2}\right]^{1}$ & 16949 & 15243 & 20618 \\
\hline$\left[\mathrm{VO}(\mathrm{OH})\left(\mathrm{C}_{4} \mathrm{H}_{8} \mathrm{ONCS}_{2}\right)(\mathrm{py})_{2}\right] \mathrm{OH} \cdot \mathrm{H}_{2} \mathrm{O}$ & Not detected & 20400 & 23696 \\
\hline$\left[\mathrm{VO}\left(\mathrm{C}_{4} \mathrm{H}_{8} \mathrm{ONCS}_{2}\right)_{2}\right]^{1}$ & Not detected & 15384 & 19230 \\
\hline
\end{tabular}

${ }^{1}$ ref 1

Table 4. Thermal data of $\left[\mathrm{VO}(\mathrm{L})_{2}\right] \cdot \mathrm{py}$ and $\left[\mathrm{VO}(\mathrm{OH})(\mathrm{L})(\mathrm{py})_{2}\right] \mathrm{OH} \cdot \mathrm{H}_{2} \mathrm{O}$ (heating rate of $10^{\circ} \mathrm{C}$ in static air)

\begin{tabular}{|c|c|c|c|c|c|c|}
\hline Compound & $\Delta \mathrm{m} / \mathrm{m}$ & $\begin{array}{l}\text { Temperature } \\
\left({ }^{\circ} \mathrm{C}\right) 25-150\end{array}$ & $\begin{array}{l}\text { Temperature } \\
\left({ }^{\circ} \mathrm{C}\right) 150-220\end{array}$ & $\begin{array}{l}\text { Temperature } \\
\left({ }^{\circ} \mathrm{C}\right) 220-380\end{array}$ & $\begin{array}{l}\text { Temperature } \\
\left({ }^{\circ} \mathrm{C}\right) 380-430\end{array}$ & $\begin{array}{l}\text { Temperature } \\
\left({ }^{\circ} \mathrm{C}\right) 430-500\end{array}$ \\
\hline$\left[\mathrm{VO}\left(\mathrm{C}_{6} \mathrm{H}_{11} \mathrm{HNCS}_{2}\right)_{2}\right] \cdot \mathrm{py}$ & $\begin{array}{l}\% \text { Calcd } \\
\% \text { Found }\end{array}$ & & & & & $\begin{array}{l}81.5 \\
79.9\end{array}$ \\
\hline$\left.\left[\mathrm{VO}\left(i-\mathrm{C}_{4} \mathrm{H}_{9}\right)_{2} \mathrm{NCS}_{2}\right)_{2}\right] \cdot \mathrm{py}$ & $\begin{array}{l}\% \text { Calcd } \\
\% \text { Found }\end{array}$ & & & & & $\begin{array}{l}83.5 \\
81.1\end{array}$ \\
\hline$\left.\left[\mathrm{VO}\left(\mathrm{C}_{3} \mathrm{H}_{7}\right)_{2} \mathrm{NCS}_{2}\right)_{2}\right] \cdot \mathrm{py}$ & $\begin{array}{l}\% \text { Calcd } \\
\% \text { Found }\end{array}$ & & & & & $\begin{array}{l}81.7 \\
80.5\end{array}$ \\
\hline$\left[\mathrm{VO}\left(\mathrm{C}_{6} \mathrm{H}_{5} \mathrm{NCS}_{2}\right)_{2}\right] \cdot \mathrm{py}$ & $\begin{array}{l}\text { \%Calcd } \\
\% \text { Found }\end{array}$ & & & & & $\begin{array}{l}81.0 \\
81.4\end{array}$ \\
\hline$\left[\mathrm{VO}(\mathrm{OH})\left(i-\mathrm{C}_{3} \mathrm{H}_{7} \mathrm{NCS}_{2}\right)(\mathrm{py})_{2}\right] \mathrm{OH} \cdot \mathrm{H}_{2} \mathrm{O}$ & $\begin{array}{l}\% \text { Calcd } \\
\% \text { Found }\end{array}$ & $\begin{array}{l}4.0 \\
3.9\end{array}$ & $\begin{array}{l}11.5 \\
10.8\end{array}$ & $\begin{array}{l}28.9 \\
29.4\end{array}$ & $\begin{array}{l}46.3 \\
45.5\end{array}$ & $\begin{array}{l}79.9 \\
78.7\end{array}$ \\
\hline$\left[\mathrm{VO}(\mathrm{OH})\left(\mathrm{C}_{5} \mathrm{H}_{10} \mathrm{NCS}_{2}\right)(\mathrm{py})_{2}\right] \mathrm{OH} \cdot \mathrm{H}_{2} \mathrm{O}$ & $\begin{array}{l}\% \text { Calcd } \\
\% \text { Found }\end{array}$ & $\begin{array}{l}4.1 \\
3.8\end{array}$ & $\begin{array}{l}11.9 \\
10.9\end{array}$ & $\begin{array}{l}29.9 \\
29.5\end{array}$ & $\begin{array}{l}48.0 \\
47.7\end{array}$ & $\begin{array}{l}79.1 \\
79.8\end{array}$ \\
\hline$\left[\mathrm{VO}(\mathrm{OH})\left(\mathrm{C}_{4} \mathrm{H}_{8} \mathrm{ONCS}_{2}\right)(\mathrm{py})_{2}\right] \mathrm{OH} \cdot \mathrm{H}_{2} \mathrm{O}$ & $\begin{array}{l}\text { \%Calcd } \\
\% \text { Found }\end{array}$ & $\begin{array}{l}4.1 \\
3.9\end{array}$ & $\begin{array}{l}11.8 \\
11.4\end{array}$ & $\begin{array}{l}29.8 \\
29.8\end{array}$ & $\begin{array}{l}47.8 \\
48.2\end{array}$ & $\begin{array}{l}79.2 \\
80.1\end{array}$ \\
\hline Thermal reaction (description) & & $\begin{array}{l}\text { Endotherm- } \\
\text { loss of } 1 \text { water } \\
\text { molecule }\end{array}$ & $\begin{array}{c}\text { Endotherm- } \\
\text { loss of } 2 \mathrm{OH} \\
\text { molecules }\end{array}$ & $\begin{array}{c}\text { Endotherm- } \\
\text { loss of } 1 \\
\text { pyridine } \\
\text { molecule }\end{array}$ & $\begin{array}{c}\text { Endotherm- } \\
\text { loss of } 1 \\
\text { pyridine } \\
\text { molecule }\end{array}$ & $\begin{array}{l}\text { Exotherm- } \\
\text { formation } \\
\text { of } \mathrm{V}_{2} \mathrm{O}_{5}\end{array}$ \\
\hline
\end{tabular}


in the IR spectra of all the complexes, and can be assign to the stretching vibration of the $\mathrm{C}-\mathrm{N}$ bond.

The electronic spectra of the adducts and derivatives, exhibit three bands (Table 3). The first band at $14000 \mathrm{~cm}^{-1}$, can be attributed to a $\mathrm{d}-\mathrm{d}$ transition ${ }^{2} \mathrm{~B}_{2} \rightarrow{ }^{2} \mathrm{E}(\mathrm{I})$ and it is displaced to lower frequencies than in the complex $\mathrm{VO}\left(\mathrm{RNCS}_{2}\right)_{2}$, according to the displacement to lower frequencies of the $v \mathrm{~V}=\mathrm{O}$ in the IR spectra, which is indicative that this d-d transition is very sensitive to the electronic $\mathrm{O} \rightarrow \mathrm{V}$ donation. The second band at 20230-20400 $\mathrm{cm}^{-1}$ can be assigned to a ${ }^{2} \mathrm{~B}_{2} \rightarrow{ }^{2} \mathrm{~B}_{1}$ transition. This band is displaced to higher frequencies in the adducts and derivatives, due to the introduction of the base into the sixthcoordination position, and is according to the displacement of the $v(\mathrm{~V}-\mathrm{S})$ in the IR spectra. This d-d transition is sensitive to the $\mathrm{V}-\mathrm{S}$ bonding force variation. The third band about $24000 \mathrm{~cm}^{-1}$ is attributed to a ${ }^{2} \mathrm{~B}_{2} \rightarrow{ }^{2} \mathrm{~A}_{1}$ transition.

However, the coordination of a sixth ligand as pyridine to the complex $\mathrm{VO}\left(\mathrm{RNCS}_{2}\right)_{2}$ apparently displaces the sulphur atoms towards the oxygen atom with concomitant reduction of the O-V-S angles, with destabilization of the $b_{1}{ }^{*}$ level relative to the $e_{p}{ }_{p}$ and renders the Balhausen-Gray ${ }^{13}$ scheme applicable to the adducts and derivatives. In the $\mathrm{VO}\left(\mathrm{RNCS}_{2}\right)_{2}$ complexes, the three $\mathrm{d}$ - $\mathrm{d}$ transitions are assigned to ${ }^{2} \mathrm{~B}_{2} \rightarrow{ }^{2} \mathrm{~B}_{1},{ }^{2} \mathrm{~B}_{2} \rightarrow{ }^{2} \mathrm{E}(\mathrm{I})$ and ${ }^{2} \mathrm{~B}_{2} \rightarrow{ }^{2} \mathrm{~A}_{1}$ transitions respectively, according to the inverse energetic levels scheme proposed by Selbin ${ }^{14}$ for a square pyramidal structure.

The data on thermal decomposition of the adducts and derivatives complexes are given in Table 4. The thermograms of the derivatives complexes showed a first decomposition (endothermic) corresponding to loss of water molecule, a second decomposition (endothermic) corresponding to loss of $2 \mathrm{OH}^{-}$species, a thrid and fourth decomposition (endothermic) corresponding to loss of pyridine molecules and a formation of corresponding metal oxide $\left(\mathrm{V}_{2} \mathrm{O}_{5}\right)$ at 430-500 ${ }^{\circ} \mathrm{C}$. On heating, the adducts showed a decomposition (exothermic) with metal oxide formation.

\section{REFERENCES}

1. Doadrio Villarejo, A.L.; Ragel, C.V. ; Doadrio, A. ; An. Real Acad. Farmacia 1984, 50, 727.

2. Doadrio Villarejo, A.L.; Pérez, G.; Ragel, C.V.; Doadrio, A.; Anales de Química 1986, 82, 234.

3. Doadrio Villarejo, A.L.; Pérez, G.; Cabañas, E.; Anales de Química 1984, $80,238$.

4. Doadrio Villarejo, A.L.; Pérez, G.; Ragel, C.V.; Synth. React. Metal-Org. Chem. 1992, 22, 599.

5. Doadrio Villarejo, A.L.; Pérez, G.; Ragel, C.V.; Tran. Met. Chem. 1992, 17,328 .

6. Curtis, N.F.; J. Chem. Soc. 1961, 3147.

7. Selwood, P.W. ; Magnetochemistry, Interscience: New York, 1956, p. 78.

8. McCormick, J.; Can. J. Chem. 1969, 47, 4283.

9. Doadrio Villarejo, A.L.; Pérez, G.; Ragel, C.V.; Eclética Química 1993, 18,41 .

10. Martínez, J.; Lozano, R.; Román, J.; Doadrio, A.; Peña, J. L.; Polyhedron 1986, 5,1341

11. Martínez, J.; Lozano, R.; Martínez, A.; Doadrio, A.; Anales de Química 1984, 80, 271

12. Martínez, J.; Lozano, R.; Martínez, A.; Doadrio, A.; Anales de Química 1983, 79B, 486

13. Ballhausen, C. J.; Gray, H. B.; Inorg. Chem. 1962, 1, 111.

14. Selbin, J. ; Coord. Chem. Rev. 1966, 1, 2931. 